\title{
PERAN POSITIONING DALAM MEMEDIASI PENGARUH KEUNGGULAN BERSAING TERHADAP KINERJA KOPERASI DI KECAMATAN AMBULU, WULUHAN DAN BALUNG
}

\author{
ELMA FITRI UTARI \\ NUNGKY VIANA FERANITA* \\ SAMPIR ANDREAN SUKOCO \\ Program Studi Ilmu Administrasi Niaga \\ Sekolah Tinggi Ilmu Administrasi Pembangunan Jember \\ *Email: nungky_viana@stiapembangunanjember.ac.id
}

\begin{abstract}
ABSTRAK
Penelitian ini berfokus pada pengaruh keunggulan bersaing terhadap kinerja organisasi secara langsung maupun tidak langsung dengan positioning sebagai variabel mediasi. Penelitian ini merupakan penelitian kuantitatif dengan pendekatan explanantory. Populasi dalam penelitian ini adalah seluruh koperasi yang masih aktif di Kecamatan Ambulu, Wuluhan

dan Balung yang terdaftar di Dinas Koperasi dan UMKM Kabupaten Jember sebesar 30 unit. Pengambilan sampel dalam penelitian ini menggunakan teknik sampling jenuh atau teknik sensus. Analisis statistik deskriptif dalam penelitian ini mencakup deskripsi umum responden dan deskripsi variabel penelitian. Analisis statistik inferensial penelitian ini adalah analisis jalur (path Analiysis) dengan menggunakan IBM SPSS 22.

Secara keseluruhan, empat hipotesis yang diajukan dalam penelitian ini terdapat tiga hipotesis yang diterima dan satu hipotesis yang ditolak. Hasil pengujian hipotesis menujukkan bahwa terdapat satu jalur yang berpengaruh tetapi tidak signifikan yaitu keunggulan bersaing terhadap positioning, satu jalur yang tidak berpengaruh dan tidak signifikan yaitu positioning terhadap kinerja organisasi, dan satu jalur yang berpengaruh dan signifikan, yaitu keunggulan bersaing terhadap kinerja organisasi. Hasil pengujian hipotesis pengaruh tidak langsung menunjukkan bahwa terdapat satu jalur tidak langsung yang berpengaruh signifikan, yaitu keunggulan bersaing terhadap kinerja organisasi melalui positioning.
\end{abstract}

Kata Kunci: Keunggulan Bersaing, Positioing, Kinerja Organisasi, Koperasi 


\section{PENDAHULUAN}

Perkembangan lingkungan organisasi yang semakin pesat menimbulkan persaingan yang semakin tinggi, sehingga organisasi membutuhkan strategi untuk mempertahankan keberadaannya dalam jangka waktu yang panjang.

Manajemen strategis adalah seni dan ilmu penyusunan, penerapan, dan pengevaluasian keputusankeputusan, manajemen strategis berfokus pada proses penetapan tujuan organisasi, pengembangan kebijakan dan perencanaan untuk mencapai sasaran, serta mengalokasikan sumber daya untuk menerapkan kebijakan dan merencanakan pencapaian tujuan organisasi yang akan meningkatkan kinerja organisasi.

Kinerja organisasi bukan lah proses final tetapi merupakan siklus dan berkelanjutan sehingga keberadaannya menjadi suatu yang sangat penting bagi pemimpin organisasi dalam mengambil kebijakan dan meningkatkan kualitas pelaksanaan kebijakan (Leismana, Machasin dan Jahrizal, 2018). Kinerja perlu dijadikan sebagai bahan evaluasi bagi pemimpin untuk mengetahui tinggi rendahnya kinerja pada organisasi. Evaluasi kinerja ini dapat dilihat dari keunggulan bersaing yang dimiliki untuk dikomunikasikan dan diposisikan dalam benak konsumen.

Menghadapi kondisi persaingan pasar yang ketat maka organisasi juga harus menciptakan keunggulan bersaing untuk strategi yang menguntungkan organisasi dengan melakukan kerjasama untuk berkompetisi lebih efektif dalam pasar (Djodjobo dan Tawas, 2014). Organisasi yang memiliki strategi yang tepat dan dapat menyesuaikan dengan setiap aktivitas fungsi dalam organisasi serta memiliki keunikan tersendiri dalam melayani permintaan konsumen, maka konsumen tersebut akan memberikan nilai yang lebih kepada perusahaan sehingga apa yang ditargetkan dalam perusahaan bisa terpenuhi yaitu meningkatkan kinerja perusahaan.

Koperasi adalah badan hukum yang didirikan oleh orang perseorangan atau badan hukum Koperasi, dengan pemisahan 
kekayaan para anggotanya sebagai modal untuk menjalankan usaha yang memenuhi aspirasi dan kebutuhan bersama di bidang ekonomi, sosial, dan budaya sesuai dengan nilai dan prinsip koperasi. Banyaknya jumlah Koperasi di Kabupaten Jember tidak semuanya mengalami peningkatan. Banyak
Koperasi yang mengalami kebangkrutan dan gulung tikar atau tidak beroperasi lagi. Koperasi di Kecamatan Ambulu, Wuluhan dan Balung termasuk yang banyak mengalami gulung tikar dari sekian banyaknya koperasi yang ada di Kecamatan lain di Kabupaten Jember.

Tabel 1. Persentase Koperasi yang Mengalami Gulung Tikar

\begin{tabular}{|c|c|c|c|c|c|}
\hline No & $\begin{array}{c}\text { Nama } \\
\text { Kecamatan }\end{array}$ & $\begin{array}{c}\text { Koperasi } \\
\text { yang } \\
\text { terdaftar }\end{array}$ & $\begin{array}{c}\text { Koperasi } \\
\text { yang } \\
\text { masih } \\
\text { aktif }\end{array}$ & $\begin{array}{c}\text { Koperasi } \\
\text { yang } \\
\text { gulung } \\
\text { tikar }\end{array}$ & Presentase (\%) \\
\hline 1 & Ambulu & 73 unit & 12 unit & 61 unit & $61 / 73 * 100 \%=\mathbf{8 3 , 6}$ \\
\hline 2 & Wuluhan & 62 unit & 7 unit & 55 unit & $55 / 62 * 100 \%=\mathbf{8 8 , 7}$ \\
\hline 3 & Balung & 24 unit & 11 unit & 13 unit & $13 / 24 * 100 \%=\mathbf{5 4 , 2}$ \\
\hline & Jumlah & & 30 unit & & \\
\hline
\end{tabular}

Sumber data: Dinas Koperasi dan UMKM Kabupaten Jember (2016) dan observasi per Januari 2019

Dari Tabel 1 diatas dapat dilihat bahwa perbandingan antara Koperasi yang terdaftar dengan koperasi yang masih aktif sangat buruk. Kenyataan ini disebabkan oleh rendahnya kinerja organisasi dari koperasi itu sendiri, yang mengakibatkan banyak koperasi mengalami gulung tikar dan tidak dapat beroperasi lagi (tidak aktif). Kualitas sumber daya manusia (pengurus koperasi) yang rendah dalam mengelola koperasi. Strategi bersaing yang rendah ini juga mengakibatkan kurang dikenalnya organisasi oleh masyarakat atau tidak ada dalam benak masyarakat dan itu dapat mempengaruhi pertumbuhan kinerja koperasi itu sendiri.

Beberapa bukti empiris menunjukkan bahwa kinerja koperasi dipengaruhi oleh keunggulan bersaing yang dimediasi oleh positioning (Istanto, 2010). Berbeda dengan penelitian yang dilakukan 
oleh Sugara (2009), menunjukkan bahwa kinerja dipengaruhi positioning dan human capital. Sedangkan Purnama dan Setiawan (2003), menunjukkan bahwa kinerja hanya dipengaruhi oleh keunggulan bersaing saja.

\section{TINJAUAN PUSTAKA}

\subsection{Manajemen Strategi}

Manajemen strategi adalah serangkaian keputusan dan tindakan manajerial yang menentukan kinerja organisasi dalam jangka panjang. Manajemen strategi meliputi pengamatan lingkungan, perumusan strategi (perencanaan strategi atau perencanaan jangka panjang), implementasi strategi, dan evaluasi serta pengendalian. Manajemen strategi menekankan pada pengamatan dan evaluasi peluang dan ancaman lingkungan dengan melihat kekuatan dan kelemahan organisasi (Wheelen dan Hunger, 2010), manajemen strategi adalah serangkaian dari pada keputusan manajerial dan kegiatan yang menentukan keberhasilan organisasi dalam jangka panjang. Kegiatan
Berdasarkan hasil observasi dan wawancara yang peneliti lakukan dengan beberapa pengurus Koperasi dan juga hasil penelitian terdahulu, maka peneliti ingin menganalisis peran positioning dalam memediasi pengaruh keunggulan bersaing terhadap kinerja koperasi.

tersebut terdiri dari perumusan/perencanaan strategi, pelaksanaan/implementasi dan evaluasi.

Dari beberapa pengertian dan definisi diatas, dapat disimpulkan bahwa manajemen strategi adalah proses atau rangkaian kegiatan pengambilan keputusan yang bersifat mendasar dan menyeluruh, disertai dengan penetapan dan tata cara pelaksanaannya, yang dibuat oleh pimpinan dan di implementasikan oleh seluruh jajaran dan anggota didalam suatu organisasi, untuk mencapai tujuan yang telah ditetapkan.

\subsection{Keunggulan Bersaing}

Keunggulan bersaing adalah keunggulan di atas pesaing baik 
melalui harga yang lebih rendah atau dengan menyediakan lebih banyak manfaat yang mendukung penetapan harga lebih mahal, sehingga dapat memberikan nilai lebih kepada konsumen dengan menggunakan kemampuan, skill, asset, kapabilitas dan lainnya yang memampukan organisasi bersaing secara efektif di dalam industri (Sampurno, 2010). Keunggulan bersaing pada dasarnya tumbuh dari nilai/manfaat yang dapat diciptakan perusahaan bagi para pembelinya yang lebih dari biaya yang harus dikeluarkan perusahaan untuk menciptakannya. Nilai atau manfaat inilah yang bersedia dibayar oleh pembeli,dan nilai yang unggul berasal dari penawaran harga yang lebih rendah dari harga pesaing untuk manfaat setara atau penawaran manfaat unik yang melebihi harga yang ditawarkan (Porter,1994).

Aktivitas dari performa perusahaan secara khusus akan menjadi dasar untuk membangun sumber-sumber yang memiliki keunggulan bersaing. Sumbersumber perusahaan menurut Barney dan Tyler (2010) terdapat tiga sumber utama, yaitu: Sumber modal fisik yaitu teknologi. Sumber modal manusia yaitu kepandaian, Dan Sumber modal organisasi yaitu pengawasan.

Dari definisi diatas dapat ditarik kesimpulan bahwa dalam rangka meningkatkan kinerja organisasi, keunggulan bersaing dipandang sebagai sesuatu yang dapat digunakan sebagai strategi organisasi. Keunggulan bersaing dapat dipahami dengan memandang organisasi sebagai keseluruhan, berasal dari banyak aktivitas yang berlainan yang dilakukan oleh organisasi dalam mendesain, memproduksi, memasarkan, menyerahkan dan mendukung penjualan. Sehingga keunggulan bersaing adalah suatu posisi yang masih dikerjakan organisasi sebagai upaya mengalahkan pesaing.

\subsection{Positioning}

Sutojo (2009) mendefinisikan positioning sebagai tindakan menempatkan diri secara tepat di setiap segmen pasar yang dilakukan dengan jalan membandingkan kekuatan dan kelemahan organisasi dengan organisasi pesaing yang 
beroperasi dalam segmen pasar yang sama. Rumusan positioning yang dikemukakan Kenna (1985), menjelaskan perusahaan sewaktu akan melaksanakan produk positioning perlu mempertimbangkan empat hal kunci utama, disebut sebagai The Golden Rules of Product. Adapun uraiannya sebagai berikut : Perusahaan perlu mengikuti trend dan dinamika pasar, seperti trend teknologi. Perusahaan harus memfokuskan pada posisi kualitas.

Perusahaan harus mentargetkan produknya pada segmen pasar tertentu. Dan Perusahaan harus mau bereksperimen dengan tipe produk baru, kemudian memperhatikan reaksi pasar.

Dari definisi diatas dapat ditarik kesimpulan bahwa dalam menciptakan produk yang diinginkan dan sekaligus dibutuhkan pelanggan bukan merupakan hal yang mudah, apalagi menciptakan produk yang dapat mempengaruhi pikiran konsumen agar memilih produk tersebut. Untuk itu, perusahaan harus dapat mengkomunikasikan produknya dengan tepat.

\subsection{Kinerja Organisasi}

Menurut Richard et. al (2009), kinerja organisasi adalah kriteria yang paling penting dalam mengevaluasi organisasi, setiap tindakan, dan lingkungan. Indeks kinerja organisasi tercermin dalam kerangka kerja Balanced Scorecard (BSC) (Kaplan dan Norton, 2001) yang digunakan sebagai kerangka pengukuran kinerja yang menggabungkan langkah-langkah strategis kinerja non-keuangan untuk melengkapi metrik keuangan tradisional, untuk memberikan pemahaman yang sama mengenai kinerja organisasi kepada manajer dan eksekutif (Norreklit, 2000). Berdasarkan penelitian sebelumnya, untuk menggabungkan multi-dimensi dalam mengukur kinerja organisasi tidak dapat hanya mengandalkan ukuran keuangan tradisional (Kaplan dan Norton, 2001; Norreklit, 2000). Balance Scorecard Model dari Harvard Business School oleh Robert S. Kaplan dan David P. Norton, pada model ini menggunakan empat perspektif dengan titik awal strategi sebagai dasar perancangannya, sehingga 
kinerja dapat diindikasikan melalui:

(1) financial perspective (keuangan),

(2) customer perspective (pelanggan), (3) internal business process perspective (proses bisnis internal) dan (4) learning and growth perspective (tumbuh dan berkembang).

\subsection{Kerangka Pemikiran}

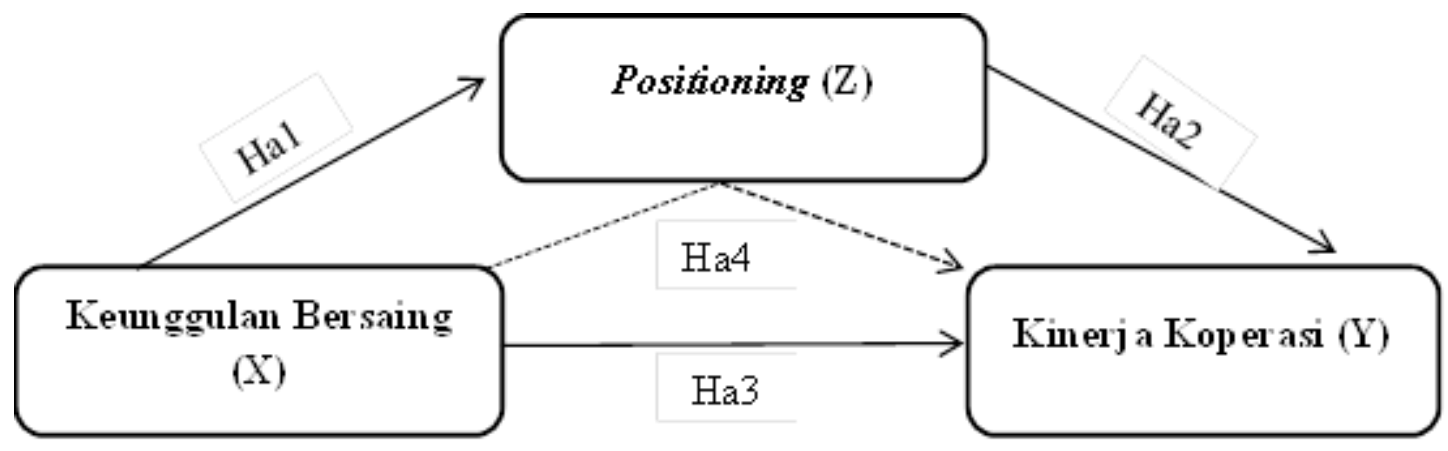

Gambar 1. Kerangka Pemikiran

\subsection{Hipotesis}
$\mathrm{Ha}_{1}$ : keunggulan bersaing berpengaruh terhadap positioning

$\mathrm{Ha}_{2}$ : positioning berpengaruh terhadap kinerja organisasi

$$
\begin{aligned}
\mathrm{Ha}_{3} & \text { keunggulan } \\
& \text { berpengaruh } \\
& \text { kinerja organisasi } \\
\mathrm{Ha}_{4} & \text { positioning } \\
& \text { pengaruh } \quad \text { keunggulan } \\
& \text { bersaing terhadap kinerja } \\
& \text { organisasi }
\end{aligned}
$$

\section{METODE PENELITIAN}

Berdasarkan tujuan yang telah ditetapkan, maka jenis penelitian ini merupakan penelitian kuantitatif. Unit analisis dalam penelitian ini adalah organisasi yang dalam hal ini diwakili pimpinan Koperasi. Lokasi yang dipilih menjadi objek penelitian adalah Koperasi di Kecamatan
Ambulu, Wuluhan dan Balung yang terdaftar di Dinas Koperasi dan UMKM Kabupaten Jember. Pemilihan di 3 Kecamatan sebagai tempat penelitian didasarkan pada kondisi yaitu di 3 kecamatan ini termasuk banyak yang sudah tidak aktif dan tidak beroperasi dari 
beberapa kecamatan lainnya yang ada di Kabupaten Jember. Populasi dalam penelitian ini adalah seluruh Koperasi baik koperasi simpan pinjam, koperasi serba usaha, koperasi unit desa, maupun koperasi tani di Kecamatan Ambulu, Wuluhan, dan Balung yang masih aktif yaitu sebanyak 30 unit koperasi.

Metode yang digunakan dalam penelitian ini adalah teknik nonprobability sampling, sedangkan teknik yang digunakan dalam penelitian ini adalah teknik sampling Jenuh, Besarnya sampel yang dijadikan responden dalam penelitian ini sebanyak 30 responden. Responden dalam penelitian ini adalah pimpinan koperasi.

Jenis data yang digunakan pada penelitian ini adalah jenis data interval. Sumber data yang

\section{HASIL PENELITIAN DAN PEMBAHASAN}

\subsection{Hasil Penelitian}

Berdasarkan hasil uji validitas seluruh item variabel memiliki nilai koefisien lebih dari 0,3610, dan berdasarkan uji reliabilitas nilai koefisien cronbach Alpha seluruh digunakan yaitu data primer dan sekunder. Data primer yang digunakan pada penelitian ini berasal dari kuesioner yang dibagikan dan diisi oleh pimpinan Koperasi di tiga Kecamatan tersebut. Sedangkan Data Sekunder yang digunakan pada penelitian ini adalah data yang berasal dari data Dinas Koperasi dan UMKM yang berupa data Koperasi yang terdapat di Kabupaten Jember.

Variabel yang digunakan dalam penelitian ini meliputi variabel independen (X) yaitu keunggulan bersaing (X), kemudian variabel mediasi (Z) yaitu positioning dan variabel dependen (Y) yaitu kinerja organisasi. Analisis data yang digunakan yaitu analisis deskriptif meliputi deskripsi responden, kemudian analisis inferensial yaitu analisis jalur (path analysis). 
Wuluhan, dan Balung memiliki pimpinan laki-laki dengan jumlah responden $21 \quad(70 \%)$. Status perkawinan yang dimiliki responden yaitu kawin sebanyak 25 responden $(83,3 \%)$. Responden lebih banyak yang sudah berusia > 35 tahun sebanyak 21 responden (70\%). Pendidikan terakhir yang ditempuh yaitu S1 dengan jumlah 25 responden $(83,3 \%)$. Lama bekerja di koperasi yaitu $\geq 4$ tahun sebanyak 27 responden (90\%). Pada penelitian ini data diolah dengan uji asumsi klasik yang meliputi uji normalitas dan uji heteroskedastisitas Berdasarkan hasil SPSS penelitian ini berdistribusi normal dan bebas heteroskedastisitas. Penelitian ini juga menggunakan uji hipotesis yang menggunkan uji $\mathrm{t}$ dan uji analisis jalur, dimana terdapat dua model yang akan ditampilkan pada Tabel 2 dan 3.

Tabel 2. Hasil Uji t

\begin{tabular}{|l|l|l|l|}
\hline \multicolumn{1}{|c|}{ Variabel } & \multicolumn{1}{|c|}{$\mathbf{t}_{\text {hitung }}$} & \multicolumn{1}{c|}{$\mathbf{t}_{\text {tabel }}$} & \multicolumn{1}{c|}{ Sig } \\
\hline Keunggulan bersaing $\rightarrow$ Positioning & 2,841 & 1,703 & 0,08 \\
\hline Positioning $\rightarrow$ Kinerja Organisasi & 0,295 & 1,703 & 0,771 \\
\hline $\begin{array}{l}\text { Keunggulan Bersaing } \rightarrow \text { Kinerja } \\
\text { Organisasi }\end{array}$ & 10,578 & 1,703 & 0,00 \\
\hline
\end{tabular}

Pada uji t hipotesis diterima apabila nilai $\mathrm{t}_{\text {hitung }}>\mathrm{t}_{\text {tabel }}$ dan nilai signifikan > 0,05. Berdasarkan Tabel 2 nilai t masing-masing model yaitu :

$\begin{array}{llr}\text { a. Keunggulan } & \text { bersaing } \\ \text { terhadap positioning } & \text { maka } \mathrm{H}_{1} \\ \text { berpengaruh, tetapi tidak } & \text { diterima te } \\ \text { signifikan. } & & \end{array}$

b. Positioning terhadap kinerja organisasi tidak berpengaruh dan tidak signifikan, maka $\mathrm{H}_{2}$ ditolak.

c. Keunggulan bersaing terhadap kinerja organisasi berpengaruh dan signifikan, maka $\mathrm{H}_{3}$ diterima. 
Tabel 3. Hasil Analisis Jalur Pengaruh Langsung Variabel Independen terhadap Variabel Dependen

\begin{tabular}{|l|c|c|}
\hline \multicolumn{1}{|c|}{ Variabel } & $\begin{array}{c}\text { Koefisien } \\
\text { Jalur }\end{array}$ & sig \\
\hline Keunggulan bersaing $\rightarrow$ positioning & $0,473\left(\mathrm{~b}_{1}\right)$ & 0,008 \\
\hline Positioning $\rightarrow$ kinerja koperasi & $0,025\left(\mathrm{~b}_{2}\right)$ & 0,771 \\
\hline Keunggulan bersaing $\rightarrow$ kinerja koperasi & $0,907\left(\mathrm{~b}_{3}\right)$ & 0,000 \\
\hline
\end{tabular}

Berdasarkan Tabel 3, dapat dilihat nilai koefisien regresi/koefisien jalur yang telah terstandar dari variabel independen (X) terhadap variabel dependen $(\mathrm{Y})$ sebagai berikut:

a. Pengaruh Keunggulan Bersaing $(\mathrm{X}) \rightarrow$ Positioning (Z).

Hubungan keunggulan bersaing terhadap positioning memiliki tingkat hubungan yang sedang yaitu sebesar 0,473. Artinya peningkatan atau penurunan tingkat keunggulan bersaing, akan meningkatkan atau menurunkan positioning.

b. Positioning $(\mathrm{Z}) \rightarrow$ Kinerja Koperasi (Y).

Hubungan positioning terhadap kinerja organisasi memiliki tingkat hubungan yang sangat rendah yaitu sebesar 0,025. Artinya peningkatan atau penurunan tingkat positioning, tidak mampu untuk meningkatkan atau menurunkan kinerja koperasi.

c. Keunggulan Bersaing (X) $\rightarrow$ Kinerja Koperasi (Y).

Hubungan keunggulan Bersaing terhadap kinerja organisasi memiliki tingkat hubungan yang sangat kuat yaitu sebesar 0,907. Artinya peningkatan atau penurunan tingkat keunggulan bersaing, akan meningkatkan atau menurunkan kinerja koperasi. 
Tabel 4. Hasil Analisis Jalur Pengaruh Tidak Langsung Variabel Independen terhadap Variabel Dependen

\begin{tabular}{|l|c|}
\hline \multicolumn{1}{|c|}{ Variabel } & Total Pengaruh \\
\hline $\begin{array}{l}\text { Keunggulan Bersaing }(\mathrm{X}) \rightarrow \text { Positioning } \\
(\mathrm{Z}) \rightarrow \text { Kinerja Koperasi }(\mathrm{Y})\end{array}$ & 0,919 \\
\hline
\end{tabular}

Hasil pengujian tidak langsung disajikan pada Tabel 4 keseluruhan model II jalur tidak langsung. Interpretasi dari Tabel 4 dapat dijelaskan sebagai berikut:

Berdasarkan Tabel 4 dapat dilihat bahwa nilai total pengaruh yaitu sebesar 0,919. Hasil pengujian ini memperoleh nilai pengaruh langsung sebesar 0,907 dan nilai total pengaruh sebesar 0,919 , dengan kata lain bahwa Pengaruh Langsung $<$ Total Pengaruh, maka Ha diterima. Hubungannya yaitu apabila keunggulan bersaing meningkat, maka hal tersebut akan meningkatkan kinerja koperasi melalui positioning.

\subsection{Pembahasan}

1. Keunggulan Bersaing berpengaruh terhadap

\section{Positioning}

Hasil studi menunjukkan hipotesis $1\left(\mathrm{H}_{1}\right)$, yang mengatakan bahwa keunggulan bersaing berpengaruh terhadap positioning, diterima tetapi tidak signifikan. Penelitian ini menunjukkan bahwa keunggulan bersaing berpengaruh tidak signifikan terhadap positioning.

Hasil penelitian ini mendukung teori Porter (1994) yang menyatakan nilai atau manfaat yang bersedia dibayar oleh pembeli, dan nilai yang unggul berasal dari penawaran harga yang lebih rendah dari harga pesaing untuk manfaat setara atau penawaran manfaat unik yang melebihi harga yang ditawarkan. Hasil penelitian ini mendukung penelitian yang dilakukan oleh Istanto (2010), yang menunjukkan bahwa keunggulan bersaing berpengaruh positif terhadap positioning.

$$
\text { Apabila dicermati dalam }
$$
deskripsi variabel, indikator yang memiliki skor terendah adalah 
indikator kemampuan produksi. Hal ini membuktikan bahwa pimpinan koperasi belum mampu sepenuhnya mengkoordinasikan pekerjaan pada karyawan dalam memberikan pelayanan jasa pada anggota.

Berdasarkan hasil pengamatan di lapangan, koperasi di Kecamatan Ambulu, Wuluhan dan Balung, belum mampu dengan baik dalam memberikan pelayanan kepada setiap anggota koperasi. Misalnya, jenis koperasi yang bukan KSU dan KUD belum mampu memproduksi produk sendiri. Hal ini menunjukkan bahwa koperasi di tiga Kecamatan tersebut tidak sepenuhnya mampu untuk menciptakan keunggulan bersaing dari para pesaing lainnya.

\section{Positioning berpengaruh terhadap Kinerja Organisasi}

Hasil studi menunjukkan hipotesis $2\left(\mathrm{H}_{2}\right)$, yang menyatakan positioning berpengaruh terhadap kinerja koperasi, ditolak dengan tidak signifikan. Penelitian ini menemukan positioning berpengaruh tidak signifikan terhadap kinerja koperasi.
Secara teoritis, hasil penelitian ini tidak mendukung terhadap teori menurut Tjiptono (2008) yang dimaksud dengan posisi dalam konteks organisasi adalah cara produk, merek atau organisasi para pesaing oleh anggota saat ini maupun calon anggota. Dalam arti kata istilah positioning mengandung makna sebagai "tindakan merancang penawaran dan citra organisasi dalam rangka meraih tempat khusus dan unik dalam benak pasar sasaran dengan sedemikian rupa sehingga dipersepsikan lebih unggul dibanding para pesaing".

Hasil ini tidak mendukung penelitian sebelumnya yang dilakukan oleh Sugara (2009), yang menyatakan bahwa positioning berpengaruh signifikan terhadap kinerja. Perbedaan hasil penelitian ini dengan penelitian terdahulu bisa terjadi karena adanya perbedaan penggunaan indikator-indikator yang digunakan dalam penelitian. Penelitian ini menggukan indikatorindikator positioning yang mengarah pada penawaran harga yang lebih rendah dan keunikan manfaat dalam menarik anggota untuk menyusun 
kinerja koperasi, sedangkan indikator positioning yang digunakan dalam penelitian terdahulu lebih mengarah pada melakukan kerjasama dengan anggota untuk menyusun kinerja.

Apabila dicermati dari data yang ada di deskripsi variabel, indikator yang memiliki skor rendah adalah keunikan manfaat (kemudahan melayani anggota dan cara berkomunikasi). Artinya koperasi belum sepenuhnya menerapkan pentingnya komunikasi dengan anggota untuk menarik minat anggota agar melakukan transaksi dengan koperasi tersebut. Komunikasi yang kurang baik ini mengakibatkan banyak anggota yang kesulitan dalam melakukan transaksi.

\section{Keunggulan}

Bersaing berpengaruh terhadap

\section{Kinerja Organisasi}

Hasil studi menunjukkan hipotesis $3\left(\mathrm{H}_{3}\right)$, yang menyatakan bahwa keunggulan bersaing berpengaruh terhadap kinerja koperasi, diterima dan signifikan. Penelitian ini menunjukkan bahwa keunggulan bersaing berpengaruh positif dan signifikan terhadap kinerja koperasi.

Hasil ini mendukung teori Tambunan (2001) yang menyakatan, untuk meningkatkan keunggulan bersaing organisasi, salah satu cara yang bisa ditempuh adalah dengan mengembangkan kapabilitas ataupun kompetensi organisasi. Hail ini selaras dengan penelitian yang dilakukan oleh Istanto (2010) dan Purnama \& Setiawan (2003), yang menyatakan bahwa keunggulan bersaing berpengaruh signifikan terhadap kinerja.

Dilihat dari deskripsi variabel, indikator yang memiliki skor tertinggi adalah kepuasan dan kesetiaan. Hal ini menunjukkan bahwa melayani anggota dengan baik dan jumlah anggota yang setiap tahun meningkat, mampu meningkatkan kinerja koperasi.

Berdasarkan pengamatan di lapangan, koperasi di tiga kecamatan tersebut memiliki cara tersendiri untuk menciptakan keunggulan bersaing, koperasi lebih mementingkan kepercayaan anggota agar mampu bertahan dengan transaksi yang sudah dilakukan, 
dibandingkan perolehan laba yang diterima koperasi atau yang pihak koperasi sering menyebutnya Sisa Hasil Usaha (SHU). Hal ini dapat berdampak bagi kinerja koperasi karena adanya peningkatan jumlah anggota dari koperasi tersebut.

\section{Positioning memediasi pengaruh Keunggulan Bersaing terhadap Kinerja Organisasi}

Hasil studi menunjukkan hipotesis $4\left(\mathrm{H}_{4}\right)$, yang menyatakan positioning memediasi pengaruh keunggulan bersaing terhadap kinerja koperasi, diterima. Penelitian ini menemukan keunggulan bersaing berpengaruh positif signifikan terdadap kinerja koperasi melalui variabel positioning.

Data pada Tabel 3 dan Tabel 4 ,maka dapat diketahui bahwa pengaruh tidak langsung antara keunggulan bersaing terhadap kinerja

\section{KESIMPULAN DAN SARAN}

\subsection{Kesimpulan}

Berdasarkan pembahasan temuan studi, dapat ditarik beberapa kesimpulan. Secara keseluruhan, koperasi lebih kecil dibandingkan dengan pengaruh langsungnya pengaruh tidak langsung sebesar 0,012 dan pengaruh langsung sebesar 0,907) sehingga memberikan kontribusi yang lebih kecil dibanding pengaruh langsungnya. Kontribusi yang diberikan positioning belum cukup mampu menjadikan mediasi yang memberikan pengaruh total yang lebih besar antara keunggulan bersaing terhadap kinerja koperasi. Hal ini mendukung penelitian yang dilakukan oleh Istanto (2010), yang menyatakan bahwa positioning mampu memediasi pengaruh keunggulan bersaing terhadap kinerja, tetapi pada penelitian terdahulu pengaruh variabel mediasi cukup besar dibanding dengan penelitian ini, sehingga dapat disimpulkan bahwa keunggulan bersaing berpengaruh terhadap kinerja koperasi melalui positioning.

dari empat hipotesis yang diajukan dalam penelitian ini terdapat tiga hipotesis yang diterima dan satu 
hipotesis yang ditolak, berikut penjelasannya:

1. Keunggulan bersaing terhadap positioning mempunyai tingkat hubungan korelasi yang sedang yaitu sebesar 0,473 . Berdasarkan uji $t$ dan uji signifikansi diketahui bahwa keunggulan bersaing berpengaruh tetapi tidak signifikan terhadap positioning.

2. Positioning terhadap kinerja organisasi mempunyai tingkat hubungan korelasi yang sangat rendah yaitu sebesar 0,025. Berdasarkan uji $\mathrm{t}$ dan uji signifikansi diketahui bahwa positioning tidak berpengaruh dan tidak signifikan terhadap kinerja organisasi.

3. Keunggulan bersaing terhadap kinerja organisasi mempunyai tingkat hubungan korelasi yang sangat kuat yaitu sebesar 0,907. Berdasarkan uji $t$ dan uji signifikansi diketahui bahwa keunggulan bersaing berpengaruh dan signifikan kinerja organisasi.

4. Dari hasil uji analisis jalur diketahui bahwa pengaruh langsung $(0,907)<$ total pengaruh $(0,919)$. Artinya keunggulan bersaing memengaruhi kinerja organisasi secara tidak langsung melalui positioning.

\subsection{Saran}

Berdasarkan keterbatasan penelitian, maka saran yang diajukan dalam penelitian ini yaitu:

1. Bagi pimpinan koperasi sebaiknya mempertahankan segala kebutuhan yang harus diterima oleh para karyawannya, seperti kebutuhan fisiologis, kebutuhan akan rasa aman, kebutuhan sosial dan kebutuhan akan penghargaan.

2. Bagi pimpinan hendaknya melakukan peningkatan dan pengembangan terhadap karyawan melalui pelatihan dan penyuluhan perkoperasian

3. Bagi pimpinan sebaiknya meningkatkan lagi motivasi kerja agar karyawan bisa bekerja lebih baik lagi.

4. Bagi pimpinan harus mampu mengelola koperasi dengan baik lagi dengan memberikan 


$$
\begin{aligned}
& \text { pengarahan } \\
& \text { karyawannya } \text { agar dapad } \\
& \text { meningkatkan pelayanan yang } \\
& \text { dilakukan kepada anggota } \\
& \text { koperasi. }
\end{aligned}
$$

5. Untuk peneliti selanjutnya, hendaknya peneliti lebih memperhatikan dan mengurangi keterbatasan dalam penelitian ini

\section{DAFTAR PUSTAKA}

Barney, Jay B. \& Willim S. Hesterly. (2010). Strategic Management and Competitiv Advantage. $3^{\text {rd }}$ Edition. Person Printice Hall.

Data Dinas Koperasi Dan Usaha Mikro Kecil dan Menengah (UMKM) Kabupaten Jember Laporan Tahun 2016. http://www.umkmjember.web.i d/index.php/component/content /frontpageDiakses pada 17 Oktober 2018. Pukul 19.34 WIB.

Djodjobo. N.V, dan Tawas.N.V. (2014). Pengaruh Orientasi Kewirausahaan, Inovasi Produk, Dan Keunggulan Bersaing Terhadap Kinerja Pemasaran Usaha Nasi Kuning Di Kota Manado. Jurnal Riset Ekonomi, Manajemen, Bisnis dan Akuntansi (EMBA) Vol.2 No.3 Hal. 1214-1224.

https://ejournal3.undip.ac.id/in dex.php/djom/article/download 117347/16602. Diakses pada 20 Januari 2019. Pukul 10.32 WIB.

Istanto, Yuni (2010). Pengaruh Strategi Keunggulan Bersaing

\begin{abstract}
diantaranya lingkup tempat
penyebaran kuesioner yang

sama, kesungguhan dan

kejujuran koresponden didalam mengisi kuesioner, perbedaan persepsi koresponden, dan survey yang hanya dilakukan satu kali agar terlaksana penelitian yang lebih baik lagi.
\end{abstract}

Dan Positioning Terhadap Kinerja (Survey Pada Koperasi Serba Usaha Di Kabupaten Sleman Yogyakarta). Buletin Ekonomi Vol. 8, No. 2 hal 70170.

http://repository.upnyk.ac.id/24 39/1/Yuni_is_sri_susilo082011 juli.pdf. Diakses pada 29 September 2018. Pukul 21.17 WIB.

Kaplan, R. S., dan Norton, D. P. (2001). The Strategy Focused Organization: How Balanced Scorecard Companies Thrive in the New Business Environment, Harvard Business School Press. USA: Boston.

Kenna., Regis. MC. (1985). Relationship Marketing : Successful Strategies for The Age of The Customer. Sixth Edition. USA. Addison-Weley Publishing.

Leismana., T. I., Machasin, dan Jahrizal. (2018). Implementasi Manajemen Strategi dan Pengaruhnya Terhadap Kepemimpinan Strategi dan Kinerja Organisasi Studi Pada 
Dinas Kebudayaan Provinsi Riau. Jurnal Tepak Manajemen Bisnis. Vol. X No. 4.

https://ejournal.unri.ac.id/index .php/JTMB/article/view/6700/6 011. Diakses pada 26 April 2019. Pukul 12.50 WIB.

Norreklit, H. (2000). The balance on the balanced scorecard - A critical analysis of some of its assumptions. Management Accounting Research. Vol. 11 No. 1 Hal. 65-88.

https://www.sciencedirect.com/ science/article/pii/S104450059 990121X. Diakses pada 26 Desember 2018. Pukul 16.48 WIB.

Porter, M.E. (1994). Keunggulan Bersaing. Tim Penerjemah Binarupa Aksara. Jakarta: Binarupa Aksara.

Purnama, Nusya'bani., dan Setiawan, Hery. (2003). Analisis Pengaruh Sumber-sumber Keunggulan Bersaing Bidang Pemasaran Terhadap Kinerja Perusahaan Manufaktur di Indonesia. Jurnal Siasat Bisnis No. 2 Vol. 2.

https://journal.uii.ac.id/JSB/arti cle/download/1010/941.

Diakses pada 03 Januari 2019. Pukul 15.19 WIB.

Richard, P.J., Devinney, T.M., Yip, G.S., and Johnson, G. (2009). Measuring Organizational Performance: Towards Methodological Best Practice.
Journal of Management. Vol. 43 No. 2, Hal. 109-116.

https://journals.sagepub.com/do $\mathrm{i} / 10.1177 / 0149206308330560$.

Diakses pada 16 Januari 2019. Pukul 16.58 WIB.

Sampurno, (2010), Manajemen Stratejik : Menciptakan Keunggulan Bersaing yang Berkelanjutan, Yogyakarta: Gadjah Mada University Press.

Sugara, Asep. (2009). Pengaruh Strategi Positioning dan Human Capital Terhadap Kinerja Perusahaan Pada PT. Media Berlian Tanggerang, Jurnal MOZAIK Vol. III Edisi 2.

https://www.academia.edu/169 94445/. Diakses pada 03 Januari 2019. Pukul 17.59 WIB.

Sutojo, Siswanto, (2009). Manajemen Pemasaran. Edisi Kedua. Jakarta : Penerbit Damar Mulia Pustaka

Tambunan, T., (2001). Kinerja Ekspor Industri Manufaktur Indonesia. Jakarta: KADIN.

Tjiptono, Fandy, (2008). Strategi Pemasaran. Edisi Ketiga. Yogyakarta : Penerbit CV. ANDI OFFSET.

Wheelen, Thomas L., dan Hunger, J. David. (2010). Strategic Management and Business Policy Achieving Sustainability. Twelfth Edition. Pearson. 